\title{
Solidifying prognosis after surgery for renal cell carcinoma
}

\author{
Michael J. Leveridge, MD, FRCSC \\ Departments of Urology and Oncology, Queen's University, Kingston, ON
}

See related article on page 125.

Cite as: Can Urol Assoc J 2014;8(3-4):133-4. htrp://dx.doi.org/10.5489/cuai.2074 Published online April 14, 2014.

$\mathrm{D}$ ason and colleagues from Dublin, Ireland have added an interesting series to the canon of nephrectomy outcomes, and have further validated and solidified the prognostic implications of stage, grade and histology in renal cell carcinoma (RCC). ${ }^{1}$ Newer series such as this one have renewed value in that they may provide a window into RCC outcomes in an era when the peculiarities of the small renal mass (SRM) have gained prominence. ${ }^{2}$ The increasing incidence of RCC, attributed in large part to increased abdominal imaging, has typically accompanied a downward stage migration, with smaller incident masses and the expectation of lower stage and grade. Surgical series of SRM pathology have confirmed that a decreasing size of tumour is associated with increased benign diagnosis, and lower markers of aggressiveness. ${ }^{3}$ These expectations are not met here, as the increasing surgical volume is accompanied by unchanged tumour size and stage, while grade decreased as might be expected. This finding stirs the mind into seeking a biological rationale to explain it, and indeed the authors concede that reasons are not particularly obvious.

The tertiary care environment may play a role here, as referral patterns might distill more challenging cases toward these centres, while smaller or more favourable masses are handled outside. The preponderance of SRMs has also paralleled the introduction of thermal ablation techniques, active surveillance and watchful waiting due to competing risks, so smaller or more indolent-behaving masses may be more likely to escape excision. This series is also somewhat remarkable for a lower partial nephrectomy $(\mathrm{PN})$ rate than prior published series. The use of PN did increase from 3.8\% to $14.8 \%$ from the earliest to the most recent cohort, but this remains lower than the $25 \%$ to $32 \% \mathrm{PN}$ rates in recent population-based series. ${ }^{4,5}$ Furthermore, academic centres were found to use PN twice as often as non-academic centres in the analysis by Patel and colleagues. ${ }^{5}$

Small but real increases in the proportion of pT1 tumours (24.8\%-34\%) and chromophobe RCC (2.9\%-7.8\%) might slightly erode the mean grade of more recent nephrectomy specimens, as all 507 tumours were assigned a grade. Fuhrman grading itself is of interest, as interobserver reliability has not been high in published series, with kappa values ranging from 0.19 to 0.44 (fair to moderate agreement). ${ }^{6-8}$ The level of overlap or disparity between pathologists would be expected to have some impact, as the authors note.

In any case, the impact of stage, grade and histology on prognosis seems unimpeachable. The CUA currently recommends a stage-based follow-up protocol after partial or radical nephrectomy. ${ }^{9}$ Series such as these that cement the impact of more granular histopathologic elements may come to be endorsed in future guidelines, as are currently employed in the predictive models of Memorial SloanKettering, UCLA and the Mayo Clinic highlighted here. At the very least, these elements should be in mind during our post-nephrectomy patient encounters as offering some guidance and counsel.

Competing interests: Dr. Leveridge declares no competing financial or personal interests.

This paper has been peer-reviewed.

\section{References}

1. Nason GJ, McGuire BB, Kelly ME, et al. Clinico-pathological analysis of renal cell carcinoma demonstrates decreasing tumour grade over a 17-year period. Can Urol Assoc J 2014;8:125-32. http://dx.doi. org/10.5489/cuaj.1721

2. Gill IS, Aron M, Gervais DA and Jewett MA. Clinical Practice. Small Renal Mass. N Engl J Med 2010 $18 ; 362(7): 624-34$ 
3. Frank I, Blute ML, Cheville JC, et al. Solid renal tumors: an analysis of pathological features related to tumor size. J Urol 2003;170:2217-20. http://dx.doi.org/10.1097/01.ju.0000095475.12515.5e

4. Biurlin MA, Walter D, Taksler GB, et al. National trends in the utilization of partial nephrectomy before and after the establishment of AUA guidelines for the management of renal masses. Urology 2013;82:1283-9. http://dx.doi.org/10.1016/j.urology.2013.07.068

5. Patel SG, Penson DF, Pabla B, et al. National trends in the use of partial nephrectomy; a rising tide that has not lifted all boats. J Urol 2012;187:816-21. http://dx.doi.org/10.1016/i.juro.2011.10.173

6. Lang $\mathrm{H}$, Lindner $\mathrm{V}$, deFromont $\mathrm{M}$, et al. Multicenter determination of optimal interobserver agreement using the Fuhrman grading system for renal cell carcinoma: Assessment of 241 patients with > 15-year follow-up. Cancer 2005;103:625-9. http://dx.doi.org/10.1002/cncr.20812
7. Ficarra V, Martignoni G, Maffei N, et al. Original and reviewed nuclear grading according to the Fuhrman system: A multivariate analysis of 388 patients with conventional renal cell carcinoma. Cancer 2005; 103:6875. http://dx.doi.org/10.1002/cncr.20749Al-Aynati M, Chen V, Salama S, Shuhaibar H,

8. Treleaven D, Vincic L. Interobserver and intraobserver variability using the Fuhrman grading system for renal cell carcinoma. Arch Pathol Lab Med 2003;127:593-6.

9. Kassouf W, Siemens R, Morash C, et al. Follow-up guidelines after radical or partial nephrectomy for localized and locally advanced renal cell carcinoma. Can Urol Assoc J 2009;3:73-6.

Correspondence: Dr. Michael Leveridge, Kingston General Hospital, Empire 4, 76 Stuart St., Kingston, 0N K7L 2V7; leveridge@gmail.com 